\title{
Discrete choice experiment on educating value-based healthcare
}

Citation for published version (APA):

Noben, C. Y. G., Stammen, L. A., Vaassen, S., Haeren, R., Stassen, L., van Mook, W., \& Essers, B. (2021). Discrete choice experiment on educating value-based healthcare. Postgraduate Medical Journal, 97(1150), 515-520. https://doi.org/10.1136/postgradmedj-2019-137190

Document status and date:

Published: 01/08/2021

DOI:

10.1136/postgradmedj-2019-137190

Document Version:

Publisher's PDF, also known as Version of record

Document license:

Taverne

Please check the document version of this publication:

- A submitted manuscript is the version of the article upon submission and before peer-review. There can be important differences between the submitted version and the official published version of record.

People interested in the research are advised to contact the author for the final version of the publication, or visit the DOI to the publisher's website.

- The final author version and the galley proof are versions of the publication after peer review.

- The final published version features the final layout of the paper including the volume, issue and page numbers.

Link to publication

\footnotetext{
General rights rights.

- You may freely distribute the URL identifying the publication in the public portal. please follow below link for the End User Agreement:

www.umlib.nl/taverne-license

Take down policy

If you believe that this document breaches copyright please contact us at:

repository@maastrichtuniversity.nl

providing details and we will investigate your claim.
}

Copyright and moral rights for the publications made accessible in the public portal are retained by the authors and/or other copyright owners and it is a condition of accessing publications that users recognise and abide by the legal requirements associated with these

- Users may download and print one copy of any publication from the public portal for the purpose of private study or research.

- You may not further distribute the material or use it for any profit-making activity or commercial gain

If the publication is distributed under the terms of Article $25 \mathrm{fa}$ of the Dutch Copyright Act, indicated by the "Taverne" license above, 


\title{
Discrete choice experiment on educating value-based healthcare
}

\author{
Cindy Y G Noben $\left(\mathbb{0}^{1}{ }^{1}\right.$ Lorette A Stammen, ${ }^{2}$ Sanne Vaassen, ${ }^{3}$ Roel Haeren, ${ }^{4,5}$ \\ Laurents Stassen, ${ }^{6}$ Walther van Mook, ${ }^{7,8}$ Brigitte Essers $^{9}$
}

For numbered affiliations see end of article.

\section{Correspondence to}

Cindy Y G Noben, Academy of Postgraduate Medical

Education, Maastricht University Medical Centre+, PO BOX 5800, Maastricht 6202 AZ, Netherlands;

cindy.noben@mumc.nl

Received 30 September 2019 Revised 19 March 2020 Accepted 20 June 2020 Published Online First 12 August 2020

\section{Check for updates}

(c) Author(s) (or their employer(s)) 2021. No commercial re-use. See rights and permissions. Published by BMJ.

To cite: Noben CYG

Stammen $L A$, Vaassen $S$,

et al. Postgrad Med J

2021:97:515-520.

\begin{abstract}
Introduction Identifying costs and values in healthcare interventions as well as the ability to measure and consider costs relative to value for patients are pivotal in clinical decision-making and medical education. This study explores residents' preferences in educating valuebased healthcare (VBHC) during postgraduate medical education. Exploring residents' preferences in VBHC education, in order to understand what shapes their choices, might contribute to improved medical residency education and healthcare as a whole.

Methods A discrete choice experiment (DCE) examined which conditions for educating VBHC are preferred by residents. DCE gives more insight into the trade-off's residents make when choosing alternatives, and which conditions for educating VBHC have the most influence on residents' preference.

Results This DCE shows that residents prefer knowledge on both medical practice as well as the process of careto be educated by an expert on VBHC together with a clinician. They prefer limited protected time to conduct VBHC initiatives (thus while at work) and desire the inclusion of VBHC in formal educational plans.

Conclusion When optimising graduate and postgraduate medical education curricula, these preferences should be considered to create necessary conditions for the facilitation and participation of residents in VBHC education and the set-up of VBHC initiatives.
\end{abstract}

\section{INTRODUCTION}

For decades, steadily increasing healthcare expenditures have been challenging the sustainability of the healthcare sector. ${ }^{1}$ Cost-effectiveness, high-value cost-conscious care and value-based healthcare (VBHC) fundamentally consider costs and outcomes, relative to each other. Based on the definition of Porter (2010), value, adopted from economics, considers the output relative to the input, for example, health gain relative to unit costs. ${ }^{2}$ Cost-effectiveness analyses compare the relative value of different healthcare interventions. ${ }^{3}$ In popular words: the themes all address 'getting bang for the healthcare buck'. In an attempt to increase cost-considerations at patient-level as part of medical decision-making, VBHC should become incorporated in medical residency education.

Therefore, knowledge of costs and value of healthcare interventions is crucial in the provision of care and clinical decision-making. However, knowledge of VBHC is often not formally included in graduate and postgraduate medical education curricula. ${ }^{45}$ As residents are tomorrow's healthcare professionals, and training is known to influence physician's behaviour, postgraduate medical education should benefit from the inclusion of VBHCprinciples and methods to help ensure the healthcare sectors' sustainability. ${ }^{6-8}$

Residents acknowledge the importance of VBHC and think that training institutions are responsible to address this topic. ${ }^{7}$ Some of the leading national physician associations, such as The American College of Physicians and the American Board of Internal Medicine, share this view, resulting in the development of curricula that promote VBHC. ${ }^{18-10}$ Additionally, incorporating $\mathrm{VBHC}$ in postgraduate medical education has shown to be effective regarding training and stimulating non-medical (CanMEDs) competencies, thereby positively affecting the development of skills as medical expert, leader, communicator and collaborator. ${ }^{11} 12$

Nonetheless, in contrast to the observed rise in the number of VBHC curricula guidelines, incorporation of VBHC educational interventions into postgraduate medical education curricula lags behind. ${ }^{8} 13$ Research has shown that even if a formal VBHC educational programme is in place, a substantial number of residents is still not involved in the related activities. This lack of involvement might be due to insufficient time to participate in the projects or lack of awareness of the activities organised. ${ }^{8}$ Aiming to increase involvement made us wonder whether we have enough understanding of the conditions residents consider important, motivating them to participate in education on VBHC.

Based on economic principles, comparing postgraduate education with a commodity and subsequently assessing the value of that commodity, it is indeed necessary to consider the customers' perspective. ${ }^{14}$ Otherwise said, to develop a commodity (ie, postgraduate medical education programmes on VBHC), that is of relevance to its users (ie, meeting the needs and preferences of residents), educational developers need to consider the preferences of their users to better meet the needs of the residents and develop options that matter to them. One of the methods to measure preferences is the discrete choice experiment (DCE). ${ }^{14}$ Based on these findings, we can tailor the way postgraduate medical education on VBHC is provided and suggest how different aspects in educating VBHC might be optimised.

Thus, choices residents make in medical education are influenced by their preferences for alternatives provided to them. By presenting them options, consisting of multiple attributes with different 
levels, we aim to assess the value residents place on each attribute, relative to the other, when making their ultimate choice. By quantifying the values respondents place in these attributes, the following research question is addressed: 'Which of the attributes for educating value-based healthcare in postgraduate medical education is the most influential?'

\section{METHODS}

\section{Contextual information: the Netherlands}

In the Netherlands, medical school takes 6 years, after which recently graduated physicians apply for residency training also known as postgraduate medical education. Residency training is organised in one of the eight healthcare education and training regions in the Netherlands. These regions contain diverse healthcare organisations such as university medical centres, educating hospitals and specialised clinics. This study was conducted in the south-east education and training region (in Dutch: OORZON), training approximately 800 residents in 35 medical disciplines. ${ }^{15}$

\section{Case description: the south-east region}

Since 2006, a nationwide competency-based framework, based upon the CanMEDS framework, is used to train residents in both medical and non-medical competencies in postgraduate medical education. ${ }^{12} 16$ Additionally, as an attempt to further train residents' competencies, VBHC is labelled one of the core themes incorporated in the regional residency training. A wide range of educational methods can be applied in medical practice. One can think of structured educating (such as simulations and journal clubs) and clinical educating (during rounds or at the patient's bedside), addressing and referring to VBHC where possible.

In our region (OORZON), education on VBHC mainly consists of interactive sessions. These are designed to flexibly incorporate the whole concept of efficiency in healthcare and emphasise the importance of critically examining whether treatments add value to the patient into the existing transdisciplinary educational structure (eg, an academic half-day morning workshop or preclinical conference). The sessions include small-group interactive learning and diverse didactic components, such as the inclusion and conduction of a local initiative on VBHC. These could include initiatives regarding misuse or overuse of diagnostic treatments and testing, or inappropriate location or facilitation of care or processes of care. Despite our efforts, perceived deficiencies in current educating of VBHC were stated by practising residents in postgraduate medical education. Among others, evaluations yielded limited time and lack of participation of clinicians.

\section{Study sample}

Based on the S-estimate (sample size) of the Bayesian efficient design, 163 respondents were sufficient to estimate significant parameters for a main effect model. Paper-based questionnaires were distributed on site during different meetings for residents (ie, trainings, morning rounds, referrals, etc) by one of the researchers. The three versions (ie, blocks) of the questionnaire were equally distributed among the residents resulting in an equally distributed response rate. No questionnaire was excluded because of missing data. The questionnaire, in Dutch, can be retrieved via the first author upon request.

The study is approved by the NVMO Ethical Review Board (NERB file number: 774), which operates commissioned by the Netherlands Association for Medical Education (NVMO).

\section{What is a DCE?}

A DCE is a stated preference method, which means that study participants are presented hypothetical choice sets or scenarios, characterised by attributes and their associated levels. ${ }^{17}$ Respondents are asked to select their preferred hypothetical scenario or choice. ${ }^{18} 19$ As such, the DCE assumes that the satisfaction or utility respondents derive from a product or service depends on the levels of the characteristics or attributes of that product or service; and that respondents choose the alternative which gives the highest satisfaction/utility. ${ }^{20}$ The DCE methodology has been used in different populations, such as patients, measuring preferences for certain healthcare interventions, ${ }^{21} 22$ or clients, exploring preferences in marketing ${ }^{23}{ }^{24}$ but also within the field of education. ${ }^{14}$ A recent paper by Cleland et al elaborated on a small number of DCEs that have been used to elicit preferences on educational issues and early career choices, linked to medical education. ${ }^{14}$ Nonetheless, the use of DCEs is relatively limited in the field of postgraduate medical education.

\section{Study design: attributes and levels}

An important step when conducting a DCE is the use of qualitative research to inform the design. ${ }^{25}$ First, a reflection of recent studies was used to gain insight in stimulating factors for VBHC in postgraduate medical education. ${ }^{41426}$ Then, two focus group meetings with residents from different medical disciplines were organised to reflect upon conditions they consider important when incorporating VBHC in educational activities. In sum, questions on VBHC, educating methods on cost-considerations, value and clinical decision-making were asked. Purposeful maximum variation sampling of residents in the south-east region was used, representing a range of demographics (type of healthcare organisation, years in training, speciality, experience with VBHC), resulting in a total of 11 participants. The information derived from the focus groups resulted in a list of six attributes. The details are presented in table 1.

\section{Discrete choice design}

Based on the six attributes and their levels, a pilot design was created without any priors since there was yet no information available about the actual value of the attributes. The results and feedback on the pilot questionnaire led to some changes. Attribute 5: 'outcomes' was excluded because it was considered overlapping with the attribute 'knowledge'. Attribute 6: 'support' as a separate attribute in terms of material and personal support was excluded because the levels did not discriminate enough compared with those of the attributes knowledge (what) and provision of knowledge (who). Based on the final four attributes (see table 1, attributes 1-4) and the prior values of the pilot study, a new design was generated using the software Ngene version 1.2.1. ${ }^{27}$ A fractional factorial (Bayesian efficient main effect) design was created because a full factorial design would have resulted in 81 hypothetical scenarios (four attributes with three levels $\left.\left(3^{4}\right)\right)$. In the final design, 18 choice sets were generated. To reduce the cognitive burden on respondents, blocking was applied; resulting in three questionnaires with each six choice sets. An example of a choice set is shown in table 2 .

\section{DCE-questionnaire}

The first part of the questionnaire described the objective of the study and explained the rationale behind the DCE. Then, the 
Table 1 Attributes and levels

\begin{tabular}{|c|c|c|c|c|}
\hline $\begin{array}{l}\text { Attribute } \\
\text { number }\end{array}$ & $\begin{array}{l}\text { Attribute } \\
\text { name }\end{array}$ & Level 1 & Level 2 & Level 3 \\
\hline 1 & $\begin{array}{l}\text { VBHC } \\
\text { knowledge } \\
\text { domain }\end{array}$ & $\begin{array}{l}\text { Knowledge on } \\
\text { medical practice like } \\
\text { cost-effectiveness of } \\
\text { a treatment or } \\
\text { patient-reported } \\
\text { outcomes }\end{array}$ & $\begin{array}{l}\text { Knowledge on } \\
\text { process of care } \\
\text { like waiting } \\
\text { time }\end{array}$ & $\begin{array}{l}\text { Combination of } \\
\text { knowledge on } \\
\text { medical } \\
\text { practice and } \\
\text { process of care }\end{array}$ \\
\hline 2 & $\begin{array}{l}\text { VBHC } \\
\text { knowledge } \\
\text { provision }\end{array}$ & $\begin{array}{l}\text { By an expert on } \\
\text { VBHC }\end{array}$ & By a clinician & $\begin{array}{l}\text { By both an } \\
\text { expert on VBHC } \\
\text { and a clinician }\end{array}$ \\
\hline 3 & $\begin{array}{l}\text { Available } \\
\text { time while at } \\
\text { work }\end{array}$ & 1 day or 2 half days & $\begin{array}{l}2 \text { days or } 4 \text { half } \\
\text { days }\end{array}$ & $\begin{array}{l}\text { No time } \\
\text { available while } \\
\text { at work (ie, } \\
\text { leisure time) }\end{array}$ \\
\hline 4 & $\begin{array}{l}\text { Perpetuation } \\
\text { of the theme } \\
\text { VBHC in } \\
\text { medical } \\
\text { education* }\end{array}$ & In educational plans & $\begin{array}{l}\text { As } \\
\text { a precondition } \\
\text { for audits }\end{array}$ & $\begin{array}{l}\text { Not in } \\
\text { educational } \\
\text { plans and not } \\
\text { as } \\
\text { a precondition } \\
\text { for audits }\end{array}$ \\
\hline 5 & $\begin{array}{l}\text { VBHC } \\
\text { outcomes }\end{array}$ & $\begin{array}{l}\text { Organisational: } \\
\text { collaboration with } \\
\text { other hospitals or } \\
\text { specialist }\end{array}$ & $\begin{array}{l}\text { Educational: } \\
\text { increasing } \\
\text { learning curves }\end{array}$ & $\begin{array}{l}\text { Future } \\
\text { possibilities: } \\
\text { work on new } \\
\text { innovative } \\
\text { VBHC } \\
\text { initiatives }\end{array}$ \\
\hline 6 & Support & Material & Personal & $\begin{array}{l}\text { Combination of } \\
\text { material and } \\
\text { personal }\end{array}$ \\
\hline
\end{tabular}

*Educational plans describe in detail the learning goals and competency development aims for medical residents. Audits are conducted to assess and analyse the learning climate of medical residency education and whether residents are being trained according to their individual learning goals.

VBHC, value-based healthcare. regarding the DCE technique. A complete example of DCEquestionnaire can be retrieved via the first author on request.

\section{Data analysis}

The data were analysed with a multinominal logit regression model using Nlogit version $5 .{ }^{27}$ Since all variables are categorical, effect coding was used to determine the influence of the attribute levels on the residents' preferences. ${ }^{28}$ The reason for using effect coding is that the variables do not take a zero value for the base level but minus one. The advantage of effect coding is that a unique utility value can be estimated for the base level unlike in the case of a dummy coded variable where the base level is confounded with the overall grand mean. ${ }^{28} 29$

The following utility function was estimated:

$$
\begin{aligned}
V= & \beta 0+\beta 1 \text { knowledge }+\beta 2 \text { who }+\beta 3 \text { time } \\
& +\beta 4 \text { educational plans }+\varepsilon
\end{aligned}
$$

where ' $\mathrm{V}$ ' is the utility deriving from choosing alternative A over $B$ or vice versa, $\beta 0=$ constant and $\beta_{1}-\beta 4$ are the coefficients reflecting the influence of a particular attribute level on the utility score. The sign of the coefficient shows whether respondents prefer (positive) or do not prefer (negative) the particular level of the attribute compared to the reference level. The relative importance of the attributes is calculated by dividing the difference in utility between the highest and lowest level of an attribute by the sum of differences in utility of all attributes. ${ }^{30}$

\section{RESULTS}

A total of 197 residents were invited to participate and returned the completed questionnaire. Most respondents started residency training between 3 and 5 years ago and had limited to no experience with VBHC initiatives. Table 3 shows the respondents' background characteristics.

\section{Results of the DCE}

In general, it took residents $7.5 \mathrm{~min}$ to complete the questionnaire. Most of the respondents stated that the questions of the DCE were clear. Few respondents indicated that it was hard to make choices or were unfamiliar with the framing of the questions.

Table 4 describes the main results from the multinominal logit regression model, showing the influence of the attribute levels on the residents' preferences for conditions related to VBHC in postgraduate medical education.

Residents value a combination of knowledge on medical practice and process of care in a positive way $(\beta=0.589)$. Moreover, solely providing knowledge on efficiency related to medical practice (eg, cost-effectiveness of treatments or reduction of complaints), or on processes of care (eg, waiting time) is valued negatively. Residents' satisfaction increases when 1 day or 2 half days is available for VBHC-education while at work (the when) $(\beta=0.451)$. However, 2 days or more is not significant, while having no time available is valued negatively by residents. The combination of an expert in VBHC and a clinician providing knowledge on VBHC (the who) positively affects the residents' utility $(\beta=0.382)$. The inclusion of VBHC in educational plans 'the where' was valued less $(\beta=0.270)$. Nonetheless, residents value the levels negatively when stated that $\mathrm{VBHC}$ is solely a precondition for audits, or when VBHC is lacking as a theme in both educational plans and as a precondition for audits. The relative importance results show that available time is considered 
Table 3 Respondents' main characteristics

\begin{tabular}{|c|c|c|}
\hline \multirow[t]{5}{*}{ Healthcare organisation } & University hospital & $133(68 \%)$ \\
\hline & Teaching hospital & $43(22 \%)$ \\
\hline & Rehabilitation clinic & $7(4 \%)$ \\
\hline & Psychiatric organisation & $9(5 \%)$ \\
\hline & Unknown & $5(3 \%)$ \\
\hline \multirow[t]{27}{*}{ Specialty } & Anaesthesiology & $15(8 \%)$ \\
\hline & Cardiology & $9(5 \%)$ \\
\hline & Cardiothoracic surgery & $1(0.5 \%)$ \\
\hline & Clinical chemistry & $1(0.5 \%)$ \\
\hline & Clinical genetics & $2(1 \%)$ \\
\hline & First aid & $1(0.5 \%)$ \\
\hline & Gastroenterology & $1(0.5 \%)$ \\
\hline & Geriatrics & $1(0.5 \%)$ \\
\hline & Hospital pharmacy & $9(5 \%)$ \\
\hline & Internal medicine & $13(7 \%)$ \\
\hline & Neurology & $15(8 \%)$ \\
\hline & Neurosurgery & $4(2 \%)$ \\
\hline & Obstetrics and gynaecology & $11(6 \%)$ \\
\hline & Oral and maxillofacial surgery & $4(2 \%)$ \\
\hline & Orthopaedics & $14(7 \%)$ \\
\hline & Otorhinolaryngology & $6(3 \%)$ \\
\hline & Paediatrics & $19(10 \%)$ \\
\hline & Pathology & $7(4 \%)$ \\
\hline & Plastic surgery & $4(2 \%)$ \\
\hline & Psychiatry & $13(7 \%)$ \\
\hline & Pulmonary medicine & $8(4 \%)$ \\
\hline & Radiology & $6(3 \%)$ \\
\hline & Rehabilitation medicine & $11(6 \%)$ \\
\hline & Rheumatology & $3(2 \%)$ \\
\hline & Surgery & $9(5 \%)$ \\
\hline & Urology & $4(2 \%)$ \\
\hline & Unknown & $6(3 \%)$ \\
\hline \multirow[t]{10}{*}{ Starting year residency } & 2008 & $1(0.5 \%)$ \\
\hline & 2010 & $1(0.5 \%)$ \\
\hline & 2011 & $8(4 \%)$ \\
\hline & 2012 & $18(9 \%)$ \\
\hline & 2013 & $27(14 \%)$ \\
\hline & 2014 & $33(17 \%)$ \\
\hline & 2015 & $28(14 \%)$ \\
\hline & 2016 & $29(15 \%)$ \\
\hline & 2017 & $23(12 \%)$ \\
\hline & Unknown & $29(15 \%)$ \\
\hline \multirow[t]{3}{*}{ Experienced with VBHC initiatives } & Yes & $60(30 \%)$ \\
\hline & No & $131(67 \%)$ \\
\hline & Unknown & $6(3 \%)$ \\
\hline
\end{tabular}

VBHC, value-based healthcare.

the most important attribute (32\%), closely followed by the provision of knowledge (29\%), then who teaches the knowledge on VBHC (23\%) with perpetuation of the theme VBHC in medical education $(16 \%)$ as least important.

\section{DISCUSSION}

This study explores residents' preferences in educating VBHC during postgraduate medical education. Exploring residents' preferences in VBHC education, in order to understand what
Table 4 Regression results showing the influence of attributes on residents' utility

\begin{tabular}{|c|c|c|c|c|}
\hline \multicolumn{2}{|c|}{ Attributes and levels } & \multirow{2}{*}{$\begin{array}{l}\text { Coefficient } \\
-0.33162^{*} \\
-0.25706^{*} \\
\mathbf{0 . 5 8 8 6 7}^{*}\end{array}$} & \multirow{2}{*}{$\begin{array}{l}\text { SE } \\
0.05770 \\
0.05671 \\
\mathbf{0 . 0 5 8 1 1}\end{array}$} & \multirow{2}{*}{$\begin{array}{l}\text { RI } \\
29 \%\end{array}$} \\
\hline What & $\begin{array}{l}\text { Knowledge on medical practice } \\
\text { Knowledge on process of care } \\
\text { Combination of knowledge on } \\
\text { medical practice and process of } \\
\text { care (reference) }\end{array}$ & & & \\
\hline When & $\begin{array}{l}\text { Available time of } 1 \text { day or } 2 \text { half } \\
\text { days while at work (reference) } \\
\text { Available time of } 2 \text { days or } 4 \text { half days } \\
\text { while at work } \\
\text { - No time available while at work }\end{array}$ & $\begin{array}{l}0.45085^{*} \\
0.12037 \\
-0.57121^{*}\end{array}$ & $\begin{array}{l}0.06749 \\
0.09902 \\
0.08092\end{array}$ & $32 \%$ \\
\hline Who & $\begin{array}{l}\text { Knowledge provided by an expert on } \\
\text { VBHC } \\
\text { Knowledge provided by a clinician } \\
\text { Knowledge provided by both an } \\
\text { expert on VBHC and a clinician } \\
\text { (reference) }\end{array}$ & $\begin{array}{l}-0.04055 \\
-0.34184^{*} \\
0.38239^{*}\end{array}$ & $\begin{array}{l}0.06575 \\
0.06054 \\
0.06460\end{array}$ & $23 \%$ \\
\hline Where & $\begin{array}{l}\text { Theme included in educational } \\
\text { plans (reference) } \\
\text { Theme as a precondition for audits } \\
\text { Theme not in educational plans nor as } \\
\text { a precondition for audits }\end{array}$ & 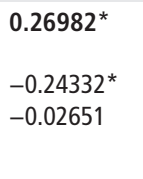 & $\begin{array}{l}0.05860 \\
0.08106 \\
0.06091\end{array}$ & $16 \%$ \\
\hline
\end{tabular}

* $\leq$ Significance at 1\% level | Log-likelihood: 698.72 | Number of observations: 1182 | Number of individuals: 197.

Reference level effect coding: $-1 \times$ (sum of the coefficients of the other two levels).

$\mathrm{RI}$, relative importance.

shapes their choices might contribute to improved medical residency education and healthcare as a whole. Based on the preferences of 197 residents, we could identify different conditions. Before VBHC education takes off, incorporation of combined knowledge provision of VBHC (the what) was preferred in relation to medical practice and the process of care. VBHC training in postgraduate medical education needs to be executable in limited protected time, thus while at work (the when), and taught and inspired by an expert on VBHC combined with a clinician (the who) and incorporated in educational plans (the where).

Although of limited use in this field of medical education thus far, ${ }^{14}$ DCEs proved to be useful to value residents' preferences on VBHC education methods. This study sought input from practising physicians (ie, residents in postgraduate medical education) on perceived deficiencies in current educating of VBHC. At the same time, we sought recommendations for necessary content to include in future postgraduate medical education accommodating more to the resident's needs and preferences, and thereby making it more sustainable. Since we were primarily interested in which aspects residents find important when setting up and conducting a local VBHC initiative, we decided not to include an opt-out. In addition, because at the moment no different types of VBHC initiatives exist, defining relevant levels for an opt-out would have been difficult. Our study contributes to the field by adding evidence of preferences to needs, from frontline medical residents to educators.

Several qualitative studies have shown that residentparticipation in educational methods improves when the method is tailored to residents' preferences, resulting in increased effectiveness of the educational method. ${ }^{31} 32$ The importance of knowledge transmission in educational methods on VBHC has been highlighted earlier. Knowledge provision on healthcare efficiency should be incorporated in medical practice and the process of care. ${ }^{26}$ Further, several studies discuss that one should 
not only focus on the components of an educational message but also need to make sure it is told by the right person(s). In addition, residents' acceptance of an educational method depends on those who provide the information. ${ }^{33}$ Finally, including different disciplines maximises residents' learning. ${ }^{34}$ These findings are in line with our significantly valued findings on knowledge provision by a combination of experts with different backgrounds (ie, an expert on VBHC in combination with a clinician). Additionally, readily observable in practice, residents closely collaborate with each other and residents' workloads are directly related to each other. Adjustments in one's own workload immediately leads to changes in other residents' workload. ${ }^{35}$ Days off from clinical practice for VBHC education might potentially endanger colleagues' workload, which thereafter might lead to higher job demands. ${ }^{35} 36$ The finding that residents value the inclusion of VBHC in educational plans positively confirms that they consider it an important topic that should be part of postgraduate medical education. ${ }^{7}$ However, VBHC as a precondition for audits is not preferred. This might perhaps be due to the assumption that the inclusion in educational plans is less strict and binding compared to the theme being a precondition in postgraduate medical education quality assurance and audit procedures.

\section{Strengths and limitations}

A wide range of residents (ie, specialities and year of residency training) were included, making the study's findings representative for the whole group of residents especially compared to a limited number of other studies on VBHC education for residents in which the majority only included residents of one specific specialty. ${ }^{73136}$ Furthermore, our study focused on guidance provision in education and the actual educating of VBHC, and not solely on providence of guidelines to foster VBHC. ${ }^{37} 38$ Although the setting was limited to one region in the Netherlands, the way Dutch medical education is organised as well as the latest developments in Dutch medical education, such as the increasing focus on residents' CanMEDS competencies, are comparable with other countries. ${ }^{6} 16$ This makes our study results applicable to a broader audience within postgraduate medical education and VBHC education.

\section{CONCLUSION}

The results of this DCE show that residents prefer to have knowledge on both medical practice as well as the process of care, to be educated by an expert on VBHC together with a clinician, to receive 1 day or 2 half days protected time, thus while at work for, educational purposes, and inclusion of VBHC in educational plans. With the results of this study, necessary conditions can be created to facilitate residents in

\section{Main messages}

- DCE methodology has the potential to address similar (VBHC-) education topics in order to provide more refined information than some traditional approaches.

- Facilitate residents in VBHC education and setting up VBHC initiatives by incorporation knowledge provision of VBHC in relation to medical practice as well as the process of care.

- Improve resident-participation in VBHC education by guarding 'limited protected time', thus while at work, to conduct VBHCinitiatives.

\section{Current research questions}

- How can we expand training in VBHC from postgraduate medical education to medical education at undergraduate level?

- Accounting for the limited protected time residents prefer, which educational methods to provide knowledge on VBHC are present or need further development?

- Can further research outline whether adjustments in medical education on VBHC, accounting for the preferences derived from the $\mathrm{DCE}$, align with satisfaction scores in educational practice?

training and setting up VBHC initiatives, resulting in improved resident-participation. Comparable educational methods on VBHC elsewhere should take residents' preferences into account as well. This will improve both medical residency education and healthcare as a whole.

\section{Author affiliations}

${ }^{1}$ Academy of Postgraduate Medical Education, Maastricht University Medical Centre+, Maastricht, Netherlands

${ }^{2}$ Department of Educational Development and Research, Maastricht University Location Randwyck, Maastricht, Netherlands

${ }^{3}$ Pediatrics, Maastricht University Medical Centre+, Maastricht, Netherlands

${ }^{4}$ Neurosurgery, Maastricht University Medical Centre+, Maastricht, Netherlands

${ }^{5}$ Department of Neurosurgery, Helsinki University Central Hospital, Helsinki, Finland

${ }^{6}$ Surgery, Maastricht University Medical Centre+, Maastricht, Netherlands

${ }^{7}$ Department of Intensive Care Medicine, Maastricht University Medical Centre+, Maastricht, Netherlands

${ }^{8}$ Department of Educational Development and Research, Maastricht University, Maastricht, Netherlands

${ }^{9}$ Clinical Epidemiology and Medical Technology Assessment, Maastricht University Medical Centre+, Maastricht, Netherlands

Acknowledgements We like to thank the respondents for their willingness to cooperate in our study. We would like to thank Marlou Kerssens, who was at the time of study finalising her internship at the department of postgraduate medical education, Maastricht University Medical Centre, and contributed to the data collection. We also thank Kieran Walsh for his advice and comments on the study and resultant paper.

Contributors CYGN, LAS, WNKAVM, BABE made substantial contributions to the design and conception of the study. CYGN and LAS were mainly involved in the acquisition of data. BAB took the lead in data analysis. From the residents' perspective, SEMV and RHLH helped the other authors with the interpretation of data. LPSS, LAS and WNKAVM further elaborated on the interpretation of the data. All authors revised the article for important intellectual content, where CYGN and BABE took the lead, mainly for the revisions. All authors approved the final version of the manuscript being submitted.

Funding The authors have not declared a specific grant for this research from any funding agency in the public, commercial or not-for-profit sectors.

Competing interests None declared.

Patient consent for publication Not required.

Ethics approval Approved by the NVMO Ethical Review Board (NERB file number: 774), which operates commissioned by the Dutch Association for Medical Education (NVMO).

Provenance and peer review Not commissioned; externally peer reviewed. Data availability statement Data are available upon reasonable request.

ORCID iD

Cindy Y G Noben http://orcid.org/0000-0002-2766-8057

\section{REFERENCES}

1 Owens DK, Qaseem A, Chou R, et al. Clinical guidelines committee of the American College of Physicians. High-value, cost-conscious health care: concepts for clinicians to evaluate the benefits, harms, and costs of medical interventions. Ann Intern Med 2011;154:174-80.

2 Porter ME. What is value in health care? N Engl J Med 2010;363:2477-81.

3 Tsevat J, Moriates C. Value-based health care meets cost-effectiveness analysis. Ann Intern Med 2018;169:329-32. 
4 Huang GC, Tibbles CD, Newman LR, et al. Consensus of the millennium conference on educating high value care. Teach Learn Med 2016;28:97-104.

5 Manja V, Monteiro S, You J, et al. Incorporating content related to value and cost-considerations in clinical decision-making: enhancements to medical education. Adv Health Sci Educ Theory Pract 2019;24:751-66.

6 Weinberger SE. Providing high-value, cost-conscious care: a critical seventh general competency for physicians. Ann Intern Med 2011;155:386-8.

7 King BC, DiPace J, Naifeh $M$, et al. Pediatric training faculty and resident perceptions on educating high-value, cost-conscious care: a multi-institutional study. Hospital Pediatrics 2017:2017-37.

8 Ryskina KL, Smith CD, Arora VM, et al. Relationship between institutional investment in high value care (HVC) performance improvement and internal medicine residents' perceptions of HVC training. Acad Med J Assoc Am MedColleges 2018;93:1517-23.

9 American College of Physicians. Newly revised: curriculum for educators and residents (Version 4.0). Available https://www.acponline.org/clinical-information/high-value-care/ medical-educators-resources/curriculum-for-educators-and-residents (accessed Mar 2018)

10 Duke P. The ABIM foundation's choosing wisely communication module. 2013. Available http://modules.choosingwisely.org/modules/m_00/default_FrameSet.htm (accessed Mar 2018)

11 Kerssens M, Noben C. High-value cost conscious care: how do we teach residents to think alike? In: Infographic Available https://www.bewustzijnsproject.nl/wp-content /uploads/2017/11/BWP-Infographic-DEF LR.pdf:Bewustzijnsproject 2017.

12 Frank JR, Danoff D. The CanMEDS initiative: implementing an outcomes-based framework of physician competencies. Med Teach 2007;29:642-7.

13 Patel MS, Reed DA, Loertscher L, et al. Educating residents to provide cost-conscious care: a national survey of residency program directors. JAMA Intern Med 2014;174:470-2

14 Cleland J, Porteous T, Skatun D. What can discrete choice experiments do for you? Med Educ 2018;52:1113-24.

15 Blinded reference for reviewing purposes.

16 Ten Cate O. Medical education in the Netherlands. Med Teach 2007;29:752-7.

17 Ryan M, Bate A, Eastmond C, et al. Use of discrete choice experiments to elicit preferences. BMJ Qual Saf 2001;10:i55-i60.

18 Louviere JJ, Lancsar E. Choice experiments in health: the good, the bad, the ugly and toward a brighter future. Health Econ Policy Law 2009;4:527-46.

19 Viney R, Lancsar E, Louviere J. Discrete choice experiments to measure consumer preferences for health and healthcare. Expert Rev Pharmacoecon Outcomes Res 2002;2:319-26.

20 Lancaster K. A new approach to consumer theory political economy. JAMA 1966:75:132-57.

21 Uemura H, Matsubara N, Kimura G, et al. Erratum to: patient preferences for treatment of castration-resistant prostate cancer in Japan: a discrete-choice experiment. BMC Urol 2017;17:20.
22 de Bekker-Grob EW, Ryan M, Gerard K. Discrete choice experiments in health economics: a review of the literature. Health Econ 2012;21:145-72.

23 Ewing G, Sarigöllü E. Assessing consumer preferences for clean-fuel vehicles: a discrete choice experiment. J Public Policy Marketing 2000;19:106-18.

24 Troiano S, Marangon F, Tempesta T, et al. Organic vs local claims: substitutes or complements for wine consumers? A marketing analysis with a discrete choice experiment. New Medit 2016;15:14-22.

25 Coast J, Al-Janabi H, Sutton EJ, et al. Using qualitative methods for attribute development for discrete choice experiments: issues and recommendations. Health Econ 2012;21:730-41.

26 Stammen LA, Stalmeijer RE, Paternotte E, et al. Training physicians to provide high-value, cost-conscious care: a systematic review. JAMA 2015;314:2384-400.

27 ChoiceMetrics. ChoiceMetrics. Econometric Software I. 2018 Available www.choicemetrics.com

28 Bech M, Gyrd-Hansen D. Effects coding in discrete choice experiments. Health Econ 2005;14:1079-83.

29 Hensher DA, Rose JM, Greene WH. Applied choice analysis. 2nd edn. Cambridge University press, 2015.

30 Malhotra NK, Birks DF. Marketing research. An applied approach. Updated second European edition. Harlow: Prentice Hall, 2006.

31 Sy A, Wong E, Boisvert L. Learning behaviour and preferences of family medicine residents under a flexible academic curriculum. Can Family Phys 2014;60: e554-e61.

32 Sawatsky AP, Zickmund SL, Berlacher K, et al. Understanding the challenges to facilitating active learning in the resident conferences: a qualitative study of internal medicine faculty and resident perspectives. Med Educ Online 2015;20:27289

33 Stinnett-Donnelly JM, Stevens PG, Hood VL. Developing a high value care programme from the bottom up: a programme of faculty-resident improvement projects targeting harmful or unnecessary care. BMJ Qual Saf 2016;25:901-8.

34 Hoff RG, Frenkel J, Imhof SM, et al. Flexibility in postgraduate medical training in the Netherlands. Acad Med 2018;93:S32-S6.

35 Prins JT, Hoekstra-Weebers JE, Gazendam-Donofrio SM, et al. Burnout and engagement among resident doctors in the Netherlands: a national study. Med Educ 2010:44:236-47.

36 Courtright KR, Weinberger SE, Wagner J. Meeting the milestones. Strategies for including high-value care education in pulmonary and critical care fellowship training. Ann Am Thorac Soc 2015;12:574-8.

37 Qaseem A, Alguire $\mathrm{P}$, Dallas $\mathrm{P}$, et al. Appropriate use of screening and diagnostic tests to foster high-value, cost-conscious care. Ann Intern Med 2012;156:147-9.

38 Chou R, Qaseem A, Owens DK, et al. Diagnostic imaging for low back pain: advice for high-value health care from the American College of Physicians. Ann Intern Med 2011;154:181-9. 